\title{
How do dairy cows chew?-Particle size analysis of selected feeds with different particle length distributions and of respective ingested bolus particles
}

\author{
I. Schadt, ${ }^{\star 1}$ J. D. Ferguson,† G. Azzaro, ${ }^{\star}$ R. Petriglieri, ${ }^{*}$ M. Caccamo, ${ }^{\star}$ P. Van Soest,‡ and G. Licitra*§ \\ ${ }^{*}$ CoRFiLaC, Regione Siciliana, 97100 Ragusa, Italy \\ †University of Pennsylvania, School of Veterinary Medicine, Kennett Square, PA 19348 \\ ¥Cornell University, Ithaca, NY 14853 \\ §Dipartimento di Scienze delle Produzioni Agrarie e Alimentari (DISPA), Catania University, Via Valdisavoia 5, 95100 Catania, Italy
}

\section{ABSTRACT}

Not only feed but also respective bolus particle size could alter diet efficiency and cow performance. The objective of this project was to characterize particle size of selected feeds and respective swallowed boli. Feed samples included 6 different particle length rye grass hay samples, 1 grass silage, 1 corn silage, and 1 total mixed ration (TMR). Rye grass hay samples consisted of long hay and chopped hay particles retained on the 19- (19_PSPS hay), 8- (8_PSPS hay), and 1.18-mm (1.18_PSPS hay) Penn State Particle Separator (PSPS) screens and those collected on the pan (PSPS_pan hay). A sixth hay treatment was rye grass forage cut at 50-mm lengths and dried to hay (50-mm hay). Treatments were offered to 4 nonlactating and 4 lactating cows following rumen evacuation. Swallowed boli were collected and the number of chews per gram of ingested feed dry matter was determined. Feed and bolus particles of lengths $\geq 5 \mathrm{~mm}$ were collected on a 1.6-mm screen using a horizontal wet sieving technique. This cut point was chosen, as the literature suggests that most fecal particles are shorter than $5 \mathrm{~mm}$. Dry matter proportions on this screen (PROP_1.6) were determined and particle lengths of retained particles were measured by image analysis. Mean particle lengths (ML) were calculated considering particles $\geq 5 \mathrm{~mm}$ in length. Boli of long hay, of 19_PSPS hay, of 8_PSPS hay, and of 50-mm hay had similar ML of 10 to 11 mm. Bolus PROP_1.6 were also similar between these treatments, ranging from 0.54 to 0.69 . Bolus particle lengths and distributions of these treatments were not related to respective hay particles. Bolus of 1.18_PSPS hay had PROP_1.6 of 0.51 and a smaller ML of $8 \mathrm{~mm}$. The PSPS_pan hay had PROP_1.6 of only 0.33 , but was still chewed intensely. Apparently, little particle

Received November 3, 2011

Accepted March 25, 2012.

${ }^{1}$ Corresponding author: schadt@corfilac.it size reduction occurred when cows ate the TMR or the silages. Feed and respective bolus PROP_1.6 were as follows: 0.66 and 0.59 in grass silage, 0.52 and 0.55 in corn silage, and 0.44 and 0.38 in the TMR. Feed and respective bolus ML were as follows: 13.8 and $11.6 \mathrm{~mm}$ in grass silage, 12.0 and $11.2 \mathrm{~mm}$ in corn silage, and 13.1 and $12.5 \mathrm{~mm}$ in the TMR. Rye grass hay particles retained on PSPS screens $\geq 8 \mathrm{~mm}$, with ML of at least $25 \mathrm{~mm}$ were longer compared with TMR particles, but respective bolus particles were shorter. Bolus particle size is not associated with the size of large feed particles chewed to a constant size that is appropriate for deglutition. This size may be related to feed chemical composition.

Key words: particle size, chewing, swallowed boli

\section{INTRODUCTION}

Feed particle size in dairy cattle diets has been associated with DMI (Allen, 1996, 2000), milk yield (Woodford and Murphy, 1988; Krause and Combs, 2003), milk composition (Yang et al., 2001; Teimouri Yansari and Primohammadi, 2009) and health effects (Shaver, 1997; Stone, 2004). However, despite years of research, it is still difficult to predict effects of dietary particle size on animal performance, and even to characterize acceptable particle size in dairy rations. The Penn State Particle Separator (PSPS) is a practical tool developed to expedite particle size estimation both in TMR and forages included in TMR for dairy cows (Lammers et al., 1996). However, recommendations of maximum amounts of feed particles over and under a certain size are rather vague (Heinrichs and Kononoff, 2004). One problem in developing feeding guidelines from the published literature might be in part due to the different methods used to estimate particle size across studies. The variation in method may contribute to the inconsistency in results across studies. Yang and Beauchemin (2005), Bhandari et al. (2007), and Asadi Alamouti et al. (2009) observed no particle size effects 
on DMI, milk yield, and fat or protein content when corn silage, alfalfa silage, or alfalfa hay with different particle dimensions were fed. Woodford and Murphy (1988) and Krause and Combs (2003) showed decreased DMI and fat content $(P<0.05)$ when smaller compared with larger forage particles were fed. Teimouri Yansari and Primohammadi (2009) observed the opposite responses. Bhandari et al. (2008) reported higher DMI $(P<0.001)$ and a trend for increased fat yield $(P=0.09)$ when short compared with long oat silage was fed. Thus, taken together, production response to dietary particle size has been quite inconsistent.

\section{Consideration of Cow Bolus Particle Size for the Evaluation of Diet Particle Size Effects on Cow Performance}

In the literature, usually only feed particle size effects but not the sizes of the chewed and ingested particles are considered. Only a few studies measured masticate or ruminal digesta particle size along with feed particle size and production data (Beauchemin et al., 2003; Kononoff and Heinrichs, 2003; Fernandez et al., 2004). Variation in the observed production responses or missing responses with varying dietary particle size may be because feed particle size does not necessarily reflect the particle size of the swallowed feed bolus (Shaver et al., 1988; Bailey et al., 1990; Pan et al., 2003). Production responses in the literature to dietary particle size may have been in part confounded by particle size of what was actually swallowed. Particle size of feed and bolus particles are related to chewing during eating and ruminating, respectively, and both sizes are related to saliva flow and ruminal $\mathrm{pH}$ as a consequence. Furthermore, size of ingested rather than the original feed particle size may be more closely related to factors such as feed passage and intake. If particle size of the original feed is not correlated to particle size of swallowed boli, then both parameters (feed particle size as well as particle size of swallowed boli) should be considered to evaluate particle size effects on cow performance and efficiency of nutrient utilization. Understanding the dynamics of feed particle reduction during chewing and how this influences the particle size of swallowed boli and eventually particle length of material retained in the rumen and passed out of the rumen are critical for assessment of adequate TMR particle size for optimal production and rumen health.

\section{Distinction of Particles Above or Below the Critical Size to Pass Out of the Rumen}

Diet particles are constituted by particles with dimensions exceeding a critical dimension for passage out of the rumen as well as smaller particles. Smaller particles are not necessarily passing out of the rumen without being regurgitated previously. Many small particles are entrapped within the rumen raft. Furthermore, they need to be soaked with rumen fluid for a certain time to achieve necessary functional specific gravity to sink and move toward the reticulo-omasal orifice (LechnerDoll et al., 1991). However, particles longer than that critical size may be more likely responsible for the functionality of the rumen raft and associated to particles which need to be regurgitated and stimulate chewing (Kennedy, 1985; Welch and Smith, 1971a,b). Kennedy (1985) and Welch and Smith (1971a) reported greatly decreased rumination times when ground and pelleted compared with long forages were fed. Welch and Smith (1971b) reported rumination cessation when alfalfa meal pellets and concentrate pellets were fed in a 1:1 ratio to 1 steer.

Measurement of Particle Length. In the literature, particle size analysis has been usually performed by sieving techniques. Depending on the sieving techniques used, either horizontal or vertical, particles are more likely separated either by their lengths or by their widths. Particle length is the bigger dimension and may represent the most limiting dimension for particles to pass out of the rumen. It also might be the dimension that is most related to the entrapment of smaller particles within the rumen raft. Igathinathane et al. (2009) reported on the inconsistency in length-based separation as a feature of mechanical sieving. They concluded that the passing of particles slightly smaller than twice the opening dimension cannot be avoided. The maximum deviation observed in particle lengths was in excess of 17 times with respect to opening dimensions of standard sieves. The authors stated that the square or circular openings of standard sieves, in the strictest sense, only allow "width-based separation" of particles. These openings truly restrict particles of width larger than the sieve opening dimension, irrespective of particle orientation with respect to the openings (Igathinathane et al., 2008). Whatever sieving technique is used, the measured particle size might not represent accurately particle length. As an alternative technique to sieving, image analysis may have limitations with regard to the sample size, as sample particles have to be separated for analysis. However, it may represent a more accurate technique to analyze particle lengths.

Critical Particle Length for Passage from the Rumen. According to Poppi et al. (1980), particles retained on a $1.18-\mathrm{mm}$ screen are highly resistant to passage from the rumen in cattle. Cardoza (1985) reported that the median fecal particles from dairy cows were retained on sieves with apertures from 0.4 to $1.2 \mathrm{~mm}$. In both studies vertical sieving techniques 
were used. Mertens (2005) suggested multiplying the mean particle size by 4.8 to approximately estimate the mean particle length. Particles retained on a $1.18-\mathrm{mm}$ screen by vertical sieving would represent particles with lengths bigger than $5 \mathrm{~mm}$. This critical particle length is supported by Kaske and Engelhardt (1990), Prigge et al. (1990), and Nørgaard and Sehic (2003).

The objective of our study was to measure lengths and DM proportions of selected feed and their respective bolus particles with lengths of at least $5 \mathrm{~mm}$. Particles with these lengths were considered to be potentially retained in the rumen. The data were used to estimate particle size reduction during ingestive mastication and to examine the relationship between feed and bolus particle distribution to investigate the influence of initial feed particle size on bolus particle size.

\section{MATERIALS AND METHODS}

\section{Animals and Feeding Protocol}

Four nonlactating multiparous and 4 lactating multiparous Holstein cows were used in the study. Cows were housed on a commercial dairy farm in Ragusa, Italy, and were fed and housed with herdmates, except during the experimental period. Cows were ruminally fistulated. Rations for dry and lactating cows were formulated according to CPM Dairy version 3.0.8 (Cornell University, Ithaca, NY; University of Pennsylvania, Kennett Square; and William H. Miner Agricultural Research Institute, Chazy, NY) to meet nutrient requirements.

Two of the nonlactating animals were not pregnant, 1 was $175 \mathrm{~d}$ pregnant and 1 was $14 \mathrm{~d}$ precalving. Nonlactating cows had an approximate BW of $670 \mathrm{~kg}$ and were fed a ration composed of ad libitum rye grass hay, which was the same cutting as used for the study, and $3 \mathrm{~kg}$ of concentrate $[18 \% \mathrm{CP}, 22 \%$ neutral detergentinsoluble fiber using heat-stable $\alpha$-amylase (aNDF), $8.5 \%$ ash, containing corn meal, soybean meal, wheat bran, minerals, and vitamins]. Grain was offered once per day from a common feed manger. The lactating animals had an approximate BW of $640 \mathrm{~kg}$ and averaged $139 \pm 73$ DIM (mean \pm SD). Mean milk production was $30.9 \pm 10.3 \mathrm{~kg} / \mathrm{d}$ (mean $\pm \mathrm{SD}$ ). Milk fat and protein content were, on average, $3.2 \pm 0.7 \%$ and $3.2 \pm 0.1 \%$, respectively (mean $\pm \mathrm{SD}$ ). Lactating cows were fed a TMR once per day, which contained $12.3 \%$ rye grass hay, $12.9 \%$ mixed grass silage, $20.9 \%$ corn silage, $28.9 \%$ corn and barley grain in equal proportions, $3.7 \%$ wheat bran, $16.6 \%$ soybean meal ( $44 \%$ CP), $1.1 \%$ SoyPass (Borregaard LignoTech, Sarpsborg, Norway), and 3.6\% of a mixed supplement containing vitamins, minerals, urea, fat, and AA. Ingredients, chemical composition
Table 1. Ingredient and chemical composition of diets, ${ }^{1}$ and intake, DIM (mean $\pm \mathrm{SD}$ ), and milk production (mean $\pm \mathrm{SD}$ ) of dry and lactating cows

\begin{tabular}{|c|c|c|}
\hline Item & $\begin{array}{l}\text { Dry cows } \\
(\mathrm{n}=4)\end{array}$ & $\begin{array}{l}\text { Lactating cows } \\
\qquad(\mathrm{n}=4)\end{array}$ \\
\hline \multicolumn{3}{|l|}{ Ingredient (\% of DM) } \\
\hline Rye grass hay & 63.4 & 12.3 \\
\hline Mixed grass silage $^{2}$ & & 12.9 \\
\hline Corn silage & & 20.9 \\
\hline Maize grain & 20.9 & 24.8 \\
\hline Barley grain & & 4.1 \\
\hline Wheat bran & 7.2 & 3.7 \\
\hline Soybean meal ( $44 \% \mathrm{CP})$ & 7.5 & 16.6 \\
\hline SoyPass $^{3}$ & & 1.1 \\
\hline $\operatorname{Mix}^{4}$ & 1.0 & 3.6 \\
\hline \multicolumn{3}{|l|}{ Chemical composition ${ }^{5}$} \\
\hline $\mathrm{DM}(\%)$ & 86.0 & 51.0 \\
\hline $\mathrm{OM}(\%$ of DM) & 90.5 & 91.1 \\
\hline $\mathrm{CP}(\%$ of $\mathrm{DM})$ & 12.6 & 16.8 \\
\hline $\mathrm{SP}(\%$ of $\mathrm{CP})$ & 23.0 & 25.4 \\
\hline aNDF ( $\%$ of DM) & 44.8 & 36.4 \\
\hline $\mathrm{ADF}(\%$ of $\mathrm{DM})$ & 26.6 & 19.5 \\
\hline Lignin $(\%$ of DM $)$ & 4.0 & 2.5 \\
\hline NFC ( $\%$ of DM) & 33.8 & 36.9 \\
\hline $\mathrm{NE}_{\mathrm{L}}(\mathrm{Mcal} / \mathrm{kg})$ & 1.4 & 1.7 \\
\hline \multicolumn{3}{|l|}{ Intake $(\mathrm{kg} / \mathrm{d})$} \\
\hline $\mathrm{DM}$ & 9.5 & 21.8 \\
\hline NDS & 55.2 & 63.6 \\
\hline DIM & & $139 \pm 73$ \\
\hline \multicolumn{3}{|l|}{ Milk production } \\
\hline Yield (kg/d) & & $30.9 \pm 10.3$ \\
\hline Fat $(\%)$ & & $3.2 \pm 0.7$ \\
\hline Protein (\%) & & $3.2 \pm 0.1$ \\
\hline
\end{tabular}

${ }^{1}$ Rations were formulated using CPM Dairy (version 3.0.8; Cornell University, Ithaca, NY; University of Pennsylvania, Kennett Square; and William H. Miner Agricultural Research Institute, Chazy, NY) for dry cows and cows in lactation.

${ }^{2}$ Triticale, barley, and rye grass.

${ }^{3}$ Borregaard LignoTech, Sarpsborg, Norway.

${ }^{4}$ Vitamin, mineral, urea, amino acid, and fat supplement.

${ }^{5} \mathrm{SP}=$ soluble protein; aNDF = neutral detergent-insoluble fiber using heat-stable $\alpha$-amylase; NDS $=$ neutral detergent solubles.

of diets, intake, and milk production are reported in Table 1. Cows were housed in a communal pen with free access to feed and water.

\section{Sampling of Feces, Rumen Mat, and Bolus, and Chewing Activities During Bolus Collection}

Prior to sampling, cows were moved to individual tie-stalls, feed was withheld for $4 \mathrm{~h}$, and a fecal sample from each cow (approximately $500 \mathrm{~g}$ ) was collected in a polyethylene bag, sealed, and placed on ice. Rumen cannulas were removed and rumens emptied in up to six 10-L buckets. A sample of rumen digesta (approximately $250 \mathrm{~g}$ of wet material) from each bucket was collected for particle size analysis, sealed, and placed on ice. Following rumen evacuation, approximately 300 $\mathrm{g}$ of hay treatments or 1,000 $\mathrm{g}$ of silage or TMR were 
offered in random sequence to each cow. Aliquots of offered feeds were collected in polyethylene bags for chemical and particle size analysis. Feed intake was calculated as the difference in feed offered and feed refused for each treatment. After swallowing 2 boli, 3 boli were caught manually through the rumen fistula from the esophageal orifice. The 3 boli were composited into a polyethylene bag, sealed, labeled with cow identification and treatment number, and placed on ice. Residual feed was removed from the feed manger to determine total ingested treatment DM and the next treatment offered. Chews were counted from the beginning of treatment feeding until completed bolus collection. Elapsed time during individual bolus collection ranged from 5 to $15 \mathrm{~min}$. Chewing was expressed as number of chews per unit of DMI by dividing total observed chews by calculated DMI. After each feed treatment, excess boli were removed from the rumen before the delivery of the next feed treatment. Treatment feeds were offered in a random sequence, in small amounts, and over a short time period to avoid confounding changes of chewing activity and particle size reduction over time with treatment effects.

\section{Treatment Feeds and Chemical Analyses}

Treatments included rye grass hay of 6 different chop lengths, a grass silage that was a mix of rye grass and triticale, a corn silage, and a TMR sample. The theoretical chop length of both silages was $10 \mathrm{~mm}$. The TMR was the basal diet for the lactating cows. Firstcut rye hay, harvested in June and stored in 250-kg round bales, fed to nonlactating cows on the farm, was used to produce 5 of 6 rye grass hay treatments in this study. Treatment 1 was long hay, with no processing. Four treatments were produced by processing a bale through a horizontal mixer wagon for approximately 12 min and separating the chopped material into 4 sizes using the PSPS with 3 screens (19-mm upper, 8-mm middle, and 1.18-mm lower) and a bottom pan. The residues on each sieve and bottom pan were collected to produce hay treatments of varying particle size (19_ PSPS hay, 8_PSPS hay, 1.18_PSPS hay, and PSPS_pan hay). Approximately $100 \mathrm{~g}$ of chopped hay from the mixer wagon was placed on the top screen of the PSPS and shaken 3 times on each side for 3 full turns. The sieving procedure was repeated until sufficient amounts of each screen and pan residue were collected. These were stored in large plastic bags until used for feeding treatments. An additional rye grass hay sample was produced by cutting fresh rye grass by hand at a constant length of $50 \mathrm{~mm}$ and drying the chopped forage to hay (50-mm hay). The fresh grass was cut at prebloom maturity, 0.75 to $1 \mathrm{~m}$ in height in the field, the day before the remaining forage was harvested to produce the baled hay.

Silages and the TMR sample were dried at $\leq 60^{\circ} \mathrm{C}$ to a constant weight. Chemical analyses consisted of the determination of DM, OM, aNDF, and $\mathrm{CP}$ content. Feeds were dried overnight at $105^{\circ} \mathrm{C}$ to obtain $\mathrm{DM}$ and ashed in a muffle furnace at $550^{\circ} \mathrm{C}$ for $4 \mathrm{~h}$ to obtain ash content and $\mathrm{OM}$ calculated by difference. We analyzed aNDF content according to Mertens (2002) using sodium sulfite and heat-stable $\alpha$-amylase (Sigma-Aldrich, Steinheim, Germany). Permanganate lignin was determined according to the method of Goering and Van Soest (1970). Nitrogen content was determined by a standard Kjeldahl procedure with $\mathrm{Cu}^{2+}$ as a catalyst, and multiplied by 6.25 to obtain CP. Silage $\mathrm{pH}$ was determined with fresh silage $(20 \mathrm{~g})$, which was immersed in $200 \mathrm{~mL}$ of distilled water and blended for $1 \mathrm{~min}$. A glass electrode accompanied by a temperature sensor was used for $\mathrm{pH}$ measurement.

\section{Particle Size Analysis}

We decided to analyze lengths of particles equal to or longer than $5 \mathrm{~mm}$. After preliminary tests, a 1.6$\mathrm{mm}$ screen was chosen to presieve samples into those $5 \mathrm{~mm}$ or longer and those shorter than $5 \mathrm{~mm}$ before image analysis, as less than $10 \%$ of fecal particles were retained on this size screen and most particles less than $5 \mathrm{~mm}$ passed through this screen, although a small proportion was still retained.

Figure 1 presents the steps involved in preparation of the particles for image analysis. Corn silage, grass silage, TMR, 1.18_PSPS hay, PSPS_pan hay, and all boli, rumen digesta, and fecal samples were sieved twice through a $1.6-\mathrm{mm}$ screen. Other feed samples were not prescreened before preparation for image analysis. Screens with retained samples were immersed in water at $20^{\circ} \mathrm{C}$, the screen rotated 4 times $90^{\circ}$ clockwise and $90^{\circ}$ counterclockwise. After each move the screen was lifted gently. We repeated the whole procedure 12 times. One sieved sample was placed in the oven and dried to a constant weight at $\leq 60^{\circ} \mathrm{C}$. Proportional DM retained on the 1.6-mm screen $\left(\mathbf{P R O P}_{\mathbf{1}} \mathbf{1 . 6}\right)$ and proportion that passed was calculated based on sample DM and DM of the screen residues. The second sieving residue was subjected to image analysis according to Licitra et al. (2005). Image analysis was performed directly on 2.5 to $3 \mathrm{~g}$ of $50-\mathrm{mm}$ hay, of 19_PSPS hay, and of 8_PSPS hay. Long rye grass hay and PSPS_pan hay could not be imaged with the current method. Some of the long grass hay particles were measured manually using a caliper. The PSPS_pan hay contained numerous small 


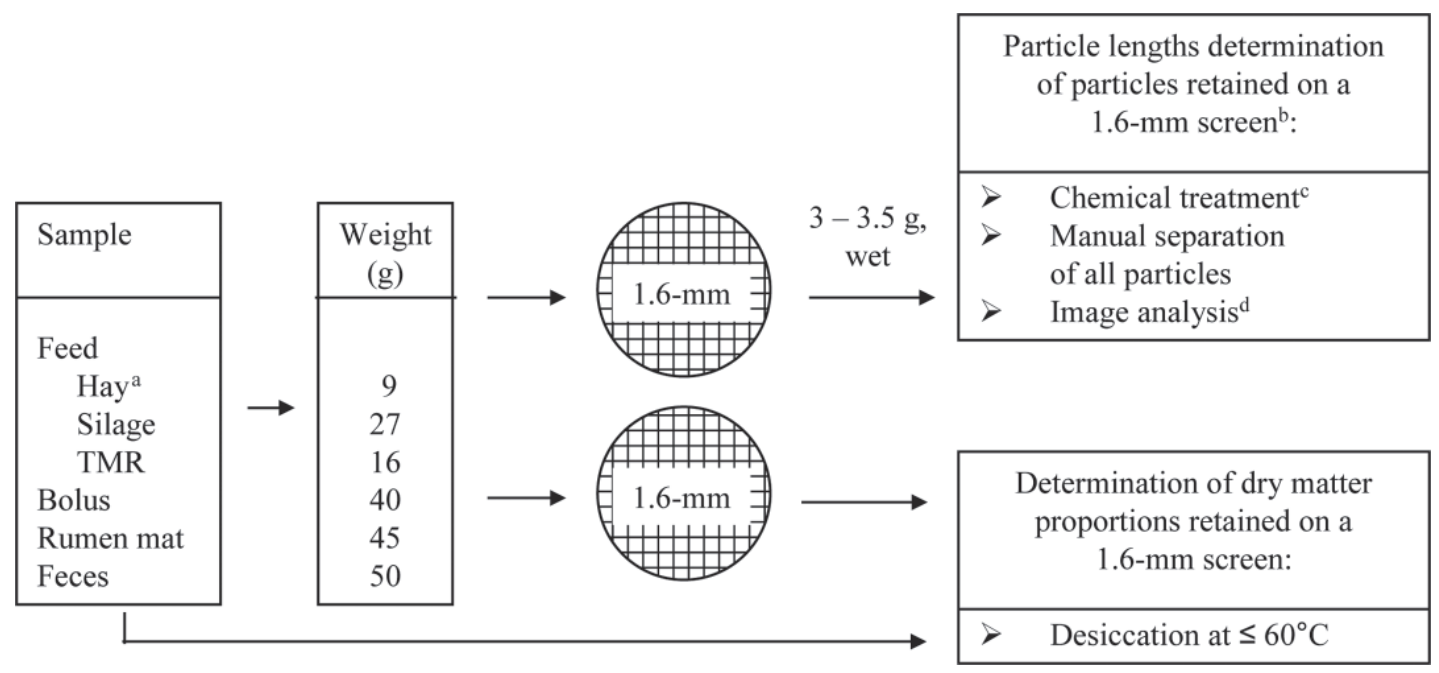

Figure 1. Experimental procedure of particle size determination: horizontal wet sieving of the sample through a sieve with 1.6-mm openings, determination of particle length distribution of sample retained, with particular attention on particles equal to or longer than 5 mm, and determination of sample DM proportion retained. ${ }^{a}$ Chopped rye grass hay particles were sieved through the Penn State Particle Separator (PSPS) to provide treatment feeds. Only hay retained on the 1.18-mm PSPS screen (1.18_PSPS hay) was sieved and imaged. Image analysis on the other chopped hay treatments was performed directly on 2.5 to $3 \mathrm{~g}$ of dry sample. The PSPS_pan hay was only sieved but not imaged. Long hay samples were neither sieved nor imaged. 'bample mean lengths were calculated considering particles equal to or longer than 5 mm. ${ }^{\mathrm{c}}$ Samples were soaked with acetone, tert-butanol, and neutral detergent to ease particle separation and dyed with safranin solution to improve image processing. ${ }^{\mathrm{d}}$ Described by Licitra et al. (2005).

particles, which were visually shorter than $5 \mathrm{~mm}$ and which we were not able to separate manually.

Samples for image analysis were soaked in acetone, NDF solution and tert-butanol to ease particle separation, and then dyed with safranin solution to improve image processing. Wet particles $(3-3.5 \mathrm{~g})$ were separated and distributed in $24 \times 36-\mathrm{cm}$ quadrants on a white nylon mesh $(0.39 \times 0.77-\mathrm{mm}$ pores $)$. Pictures were taken using a digital camera (Nikon Coolpix E 990, model no. 4112962, 3.34 megapixel; Nikon Corp., Tokyo, Japan) mounted $50 \mathrm{~cm}$ from the surface of the mesh screen. The flash was turned off and pictures were recorded at a resolution of $2,048 \times 1,536$ pixels. Images were analyzed using the image processing toolbox of Matlab (version 6.0.0.88, 2000; MathWorks Inc., Asheboro, NC) set to the local threshold technique.

\section{Statistical Analysis}

Statistical analyses were carried out with SAS (version 9.1; SAS Institute Inc., Cary, NC). A linear model was used to test for differences between the chemical composition of treatment feeds.

Particle length frequency (1-mm step) was calculated from the Matlab image analysis. Mean length (ML) of particles retained on the $1.6-\mathrm{mm}$ sieve and equal to or longer than $5 \mathrm{~mm}$, standard error, and statistical tests were determined using the SAS LIFETEST procedures.
The distribution of 1 minus the cumulative frequency proportion as a function of length (l) was computed using Equation 1.

$$
l_{\mathrm{n}}=1-\sum_{\mathrm{i}=1}^{\mathrm{n}-1} \mathrm{l}_{\mathrm{i}}
$$

where $l_{i}$ is the proportion of length $i(\mathrm{~mm})$ over the total particles.

This distribution follows a failure time curve, as the cumulative distribution function is related to the survival function by $1-\mathrm{S}(\mathrm{t})$, where $\mathrm{S}(\mathrm{t})$ is the survival distribution function evaluated at time $t$, with length (l) substituted for t. The cumulative distribution function represented the probability that a length did not exceed the lth $\mathrm{mm}$. The PROC LIFETEST, method Kaplan-Meier, was used to estimate ML. The difference in survival curves was tested using the univariate test statement in PROC LIFETEST.

The SAS MIXED procedure was used for testing differences in PROP_1.6 and ML within feeds and boli and chews per gram of DM ingested, with cows set as repeated measure. Independent variables were treatment, production level, and treatment $\times$ production level. Differences in ML within feed and bolus samples were tested with cows set as repeated measure. The covariance matrix was set as autoregressive(1). Significance was set at $P<0.05$. 
Table 2. Chemical composition of treatment feeds ${ }^{1}$

\begin{tabular}{|c|c|c|c|c|c|c|}
\hline \multirow[b]{2}{*}{ Item } & \multirow[b]{2}{*}{$\mathrm{DM}^{2}(\%)$} & \multicolumn{4}{|c|}{$\%$ of $\mathrm{DM}^{3}$} & \multirow[b]{2}{*}{$\mathrm{pH}$} \\
\hline & & Ash & $\mathrm{CP}$ & aNDF & $\mathrm{ADL}$ & \\
\hline \multicolumn{7}{|l|}{ Feed } \\
\hline Long rye grass hay & & $10.2^{\mathrm{ab}}$ & $11.7^{\mathrm{c}}$ & $57.1^{\mathrm{abc}}$ & $6.5^{\mathrm{a}}$ & \\
\hline $50-\mathrm{mm}$ hav $^{4}$ & & $10.2^{\mathrm{ab}}$ & $11.7^{\mathrm{c}}$ & $58.6^{\mathrm{ab}}$ & $6.7^{\mathrm{a}}$ & \\
\hline 19_PSPS hay ${ }^{5}$ & & $10.3^{\mathrm{ab}}$ & $11.8^{\mathrm{c}}$ & $57.9^{\mathrm{abc}}$ & $6.6^{\mathrm{a}}$ & \\
\hline 8_PSPS hay ${ }^{6}$ & & $10.6^{\mathrm{ab}}$ & $12.3^{\mathrm{c}}$ & $59.1^{\mathrm{a}}$ & $6.7^{\mathrm{a}}$ & \\
\hline 1.18_PSPS hay ${ }^{7}$ & & $11.3^{\mathrm{a}}$ & $13.7^{\mathrm{b}}$ & $54.2^{\mathrm{bc}}$ & $6.0^{\mathrm{a}}$ & \\
\hline PSPS_pan hay ${ }^{8}$ & & $11.7^{\mathrm{a}}$ & $14.4^{\mathrm{b}}$ & $54.0^{\mathrm{c}}$ & $5.5^{\mathrm{ab}}$ & \\
\hline Grass silage & $29.0^{\mathrm{b}}$ & $9.6^{\mathrm{b}}$ & $9.3^{\mathrm{d}}$ & $53.1^{\mathrm{c}}$ & $6.1^{\mathrm{a}}$ & $3.95^{\mathrm{a}}$ \\
\hline Corn silage & $29.1^{\mathrm{b}}$ & $6.4^{\mathrm{c}}$ & $9.4^{\mathrm{d}}$ & $48.1^{\mathrm{d}}$ & $4.2^{\mathrm{bc}}$ & $3.72^{\mathrm{b}}$ \\
\hline TMR & $51.3^{\mathrm{a}}$ & $7.5^{\mathrm{c}}$ & $16.7^{\mathrm{a}}$ & $37.7^{\mathrm{e}}$ & $3.7^{\mathrm{c}}$ & \\
\hline SEM & 0.90 & 0.55 & 0.42 & 1.56 & 0.31 & 0.05 \\
\hline
\end{tabular}

${ }^{\mathrm{a} e} \mathrm{Means}$ within a column with different superscripts differ at $P<0.05$.

${ }^{1}$ aNDF $=$ neutral detergent-insoluble fiber using heat-stable $\alpha$-amylase; ADL $=$ permanganate lignin.

${ }^{2}$ Dried at $\leq 60^{\circ} \mathrm{C}$.

${ }^{3}$ Dried at $100^{\circ} \mathrm{C}$.

${ }^{4}$ Rye grass cut at $50-\mathrm{mm}$ length and dried.

${ }^{5}$ Rye grass hay chopped, sieved through the Penn State Particle Separator (PSPS), and retained on the 19-mm screen.

${ }^{6}$ Rye grass hay chopped, sieved through the PSPS, and retained on the 8-mm screen.

${ }^{7}$ Rye grass hay chopped, sieved through the PSPS, and retained on the 1.18-mm screen.

${ }^{8}$ Rye grass hay chopped, sieved through the PSPS, and retained on the bottom pan.

\section{RESULTS AND DISCUSSION}

\section{Chemical Composition of Treatment Feeds}

The chemical composition of the treatment feeds is presented in Table 2. All rye grass hay treatments and the grass silage had higher ash contents of 10 to $12 \%$ DM compared with the corn silage and TMR, which had ash contents of 6 and $8 \% \mathrm{DM}$, respectively. The TMR was lowest in aNDF (38\% DM), followed by corn silage $(48 \% \mathrm{DM})$. All grass samples had similar aNDF contents $(P>0.05)$, ranging from 53 to $59 \%$ DM, which were higher compared with the corn silage and the TMR aNDF contents. All grass hay samples and the grass silage samples had similar ADL contents ranging from 5.5\% DM in the PSPS_pan hay to 6.7\% DM in the 8_PSPS hay. Corn silage and the TMR had ADL contents of 4.2 and $3.7 \%$ DM, respectively. Crude protein was highest in the TMR (17\% DM), followed by the 1.18_PSPS hay and PSPS_pan hay (14\% DM), and by the remaining rye grass hay treatments with longer particles $(12 \% \mathrm{DM})$. Silages had the lowest CP (9\% DM) content compared with all other samples. Increased CP of the 1.18_PSPS hay and of the PSPS_pan hay relative to the longer rye grass hays may be explained by a greater proportion of leaf fragments. Hay leaves contain a greater concentration of $\mathrm{CP}$ than stems and will comprise a higher proportion of finer particles when chopped, because they tend to shatter more eas- ily and form smaller particles than stems. The 50-mm hay had similar nutrient composition as the other rye grass treatments obtained from baled hay.

\section{Influence of Experimental Conditions on Ingestive Mastication}

Coulon et al. (1987) found a positive relationship between milk production and eating rate, which was attributed to the greater feeling of hunger owing to the larger requirements of the higher-producing cows. Dado and Allen (1995) fed 25 and 35\% NDF diets with or without added rumen inert bulk to rumen-cannulated cows. Additional NDF or inert bulk increased chewing time per unit of DMI. Luginbuhl et al. (1989) observed an increased rate of intake and decreased particle size reduction during ingestive mastication when feeding of steers was restricted. In the present study, before treatment feeding and bolus sampling, feed was held away from cows for $4 \mathrm{~h}$. Cows were hungry and rumen fill may have been reduced relative to the daily average. As a consequence, the number of measured chews per gram of DMI and bolus particle dimensions measured may not represent average daily measures, but observed chews per gram of DMI may be lower and bolus particles longer compared with the daily average. However, it was necessary to perform the experiment with hungry cows to avoid cows' refusal to eat the less palatable treatment feeds. 


\section{Distributions of Imaged Feed and Bolus Particles at Individual Lengths}

Comparison of the Bolus Particle Length Distributions. Figure 2 is a plot for the cumulative distributions of bolus particles retained on a 1.6- $\mathrm{mm}$ screen by measured length. The thicker lines are the silages and the TMR sample, and the thinner lines are the rye grass hay samples. Apparently, all bolus particles, with exception of the 1.18_PSPS hay, had very similar distributions of particle lengths. The boli from the 1.18_PSPS hay had the shortest particles, boli from corn silage and the other rye grass hay treatments were intermediate in lengths, and boli from grass silage and TMR contained the longest particles. Rye grass hay was apparently chewed to consistent bolus length and similar distribution of particles, independently of distribution of feed particle lengths, as long as hay particles were long enough to be retained on the 8-mm PSPS screen or longer. There might exist a threshold of maximum length of particles that can be swallowed by the cow. Particles longer than that threshold may be swallowed at similar lengths. Particle sizes of these feeds might determine the duration of the eating time, but bolus particles might have very similar distributions of particle lengths, independent of initial lengths and rumination time might be constant.

Bolus Relative to Respective Feed Particle Length Distributions. Proportions of imaged particles by length in millimeters for feed and boli retained on the 1.6-mm screen were plotted against each other for each feed treatment in Figure 3. The abscissa axis is the distribution of feed particles at individual lengths and the ordinal axis is the distribution of respective bolus particles. Length is hidden in the plots, so data points are labeled. In addition, data points above and below certain lengths are shape and color coded. Longer particles above a cut point, which were present in the main feed but not in the main bolus particle fraction, and with the main particle fraction consisting in $99 \%$ of imaged particles, are represented by black triangles. The shorter main bolus particles are represented by circles. Empty, but not full circles in Figures 3e to $\mathrm{h}$ indicate particle lengths at which feed and respective bolus particle proportions are linearly correlated.

Figure 3a shows only the bolus particle distribution along the ordinal axis. Long hay particles were not imaged and lengths distribution not plotted. In Figures $3 \mathrm{~b}$ to $\mathrm{h}$ are the plots of both treatment feed and associated bolus particle distributions, with treatments represented as follows: in Figure 3b, the 50-mm hay; in Figure 3c, the 19_PSPS hay; in Figure 3d, the 8_PSPS hay; in Figure 3e, the 1.18_PSPS hay; in Figure 3f, the grass silage; in Figure $3 \mathrm{~g}$, the corn silage; and in Figure
$3 \mathrm{~h}$, the TMR. In all hay boli, the sequence of particle lengths with decreasing bolus particle proportions appear similar (Figures 3a to e). The most frequent imaged hay bolus particles were 5 and $4 \mathrm{~mm}$ long. As hay particle size fell below a certain threshold size, a linear association of feed and bolus particles became apparent. Proportions of 50-mm hay, the 19_PSPS hay, and the 8_PSPS hay were little correlated to respective bolus particles at the same lengths (Figures 3b to d), but proportions of the 1.18_PSPS hay, in the range of 9- to 18-mm lengths, were highly associated $\left(\mathrm{R}^{2}=\right.$ 0.99 ) to bolus particle proportions (Figure 3e). The 1.18_PSPS hay had less 1- to 8-mm particles, but more 9- to 18-mm particles, compared with respective boli. The longest particles in the main bolus fraction (99\% of imaged particles) from long rye grass hay, 50-mm hay, 19_PSPS hay, and 8_PSPS hay were all approximately $3 \mathrm{~cm}$ long (Figures 3a to d). This length may represent the maximum length of rye grass hay particles that can be swallowed by the cow. Also, silage and TMR particle proportions were linearly associated with respective bolus particle proportions (Figures $3 \mathrm{f}$ to $\mathrm{h}$ ). Grass silage particle proportions were correlated $\left(\mathrm{R}^{2}\right.$ $=0.97)$ to bolus particle proportions within the range of 9- to 38-mm lengths (Figure 3f). There were more

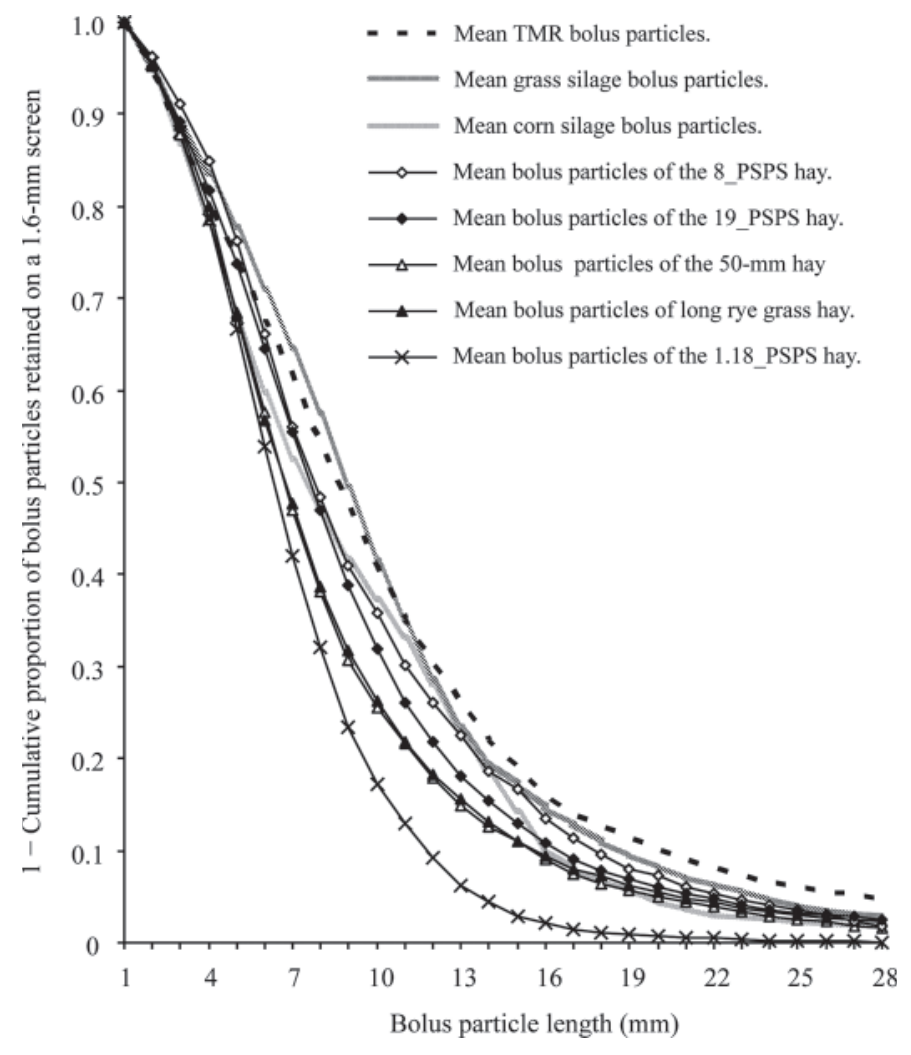

Figure 2. Plot of 1 - cumulative length distribution of bolus particles retained on a $1.6-\mathrm{mm}$ screen. 
a)

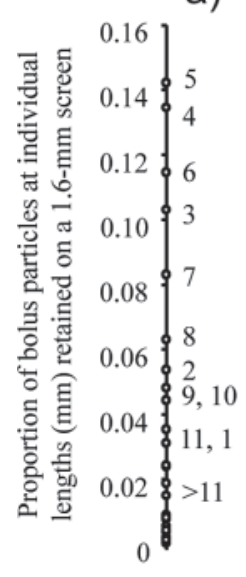

b)

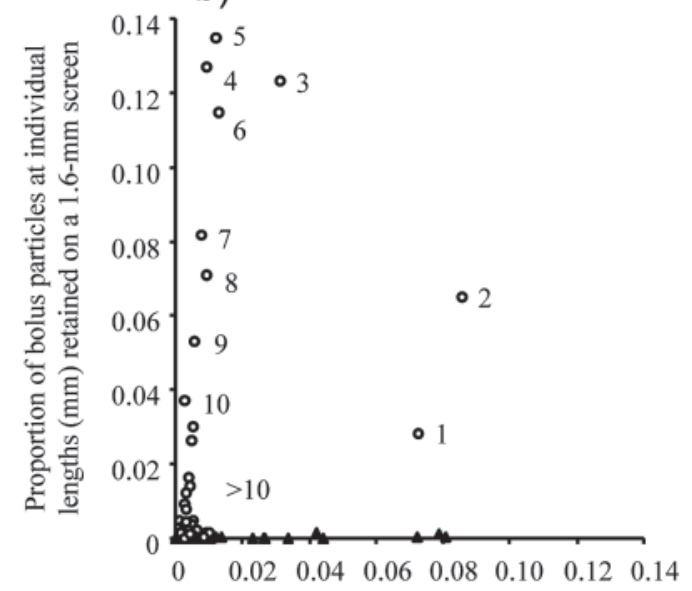

Proportion of hay particles at individual lengths (mm)

- 1- through 34-mm particles.

$<1 \%$ bolus particles were $>34 \mathrm{~mm}$.

- 35-through 104-mm particles.

$<1 \%$ hay particles were $>104 \mathrm{~mm}$.

$<1 \%$ bolus particles were $>29 \mathrm{~mm}$.

c)

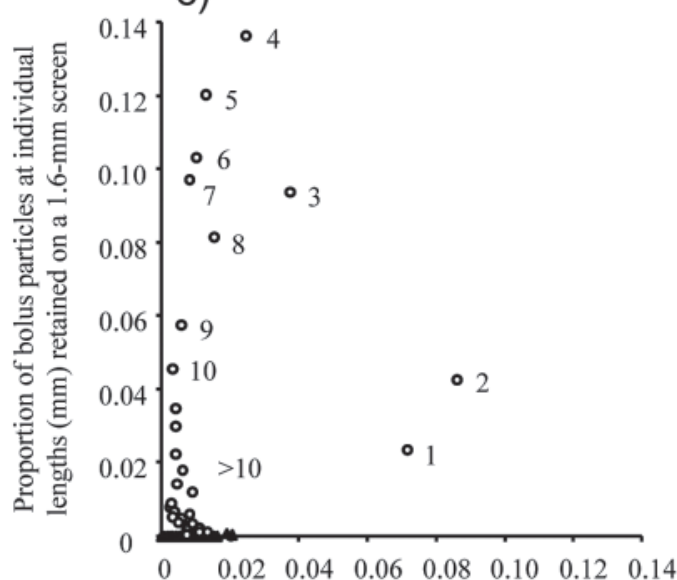

Proportion of hay particles at individual lengths (mm)

- 1- through 31-mm particles.

$<1 \%$ bolus particles were $>31 \mathrm{~mm}$.

- 32-through 138-mm particles.

$<1 \%$ hay particles were $>138 \mathrm{~mm}$. d)

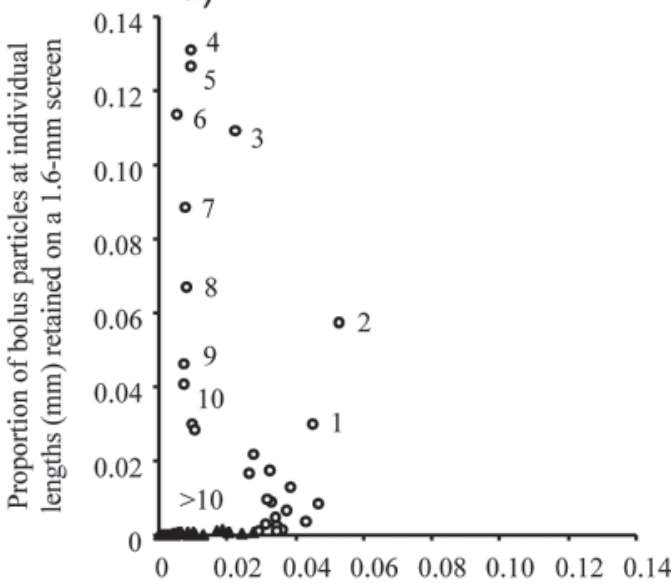

Proportion of hay particles at individual lengths (mm)

- 1- through 27-mm particles.

$<1 \%$ bolus particles were $>27 \mathrm{~mm}$.

- 28- through 76-mm particles.

$<1 \%$ hay particles were $>76 \mathrm{~mm}$.

Figure 3. Length distribution of feed particles relative to respective bolus particles from image analysis (dry and lactating cows averaged, a to h); image analysis after elimination of small particles by sieving through a 1.6-mm screen from all bolus samples (a to h) and chopped rye grass hay retained on the 1.18-mm screen of the Penn State Particle Separator (1.18_PSPS hay), grass silage, corn silage and TMR (e to h ); direct image analysis from unprocessed long rye grass hay, 50-mm hay, 19_PSPS hay and 8_PSPS hay (a to d). The numbers in the body of each graph are the particle lengths (mm). a) Long rye grass hay; b) 50-mm hay versus respective bolus particles; c) 19_PSPS hay versus respective bolus particles; d) 8_PSPS hay versus respective bolus particles; e) 1.18_PSPS hay versus respective bolus particles; f) grass silage particles versus respective bolus particles; g) corn silage particles versus respective bolus particles; h) TMR particles versus respective bolus particles. 
e)

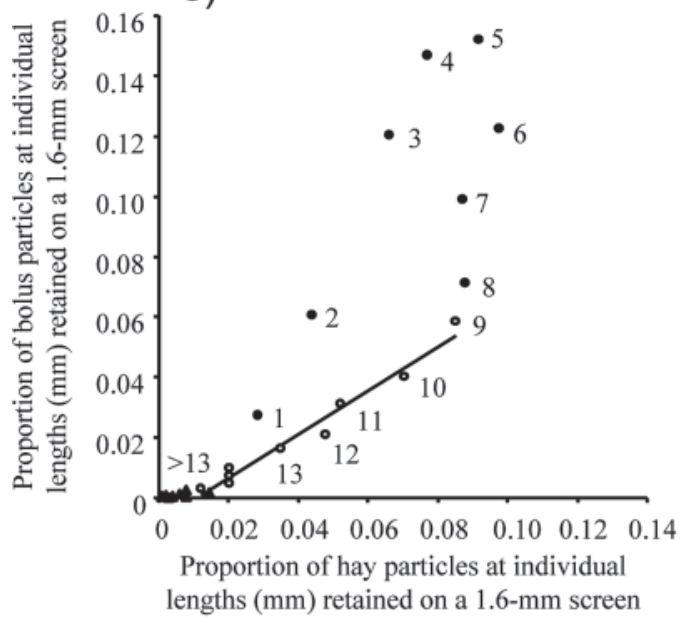

- 1- through 8-mm particles.

- 9- through 18-mm particles; $\mathrm{y}=0.785 \mathrm{x}-0.006 ; \mathrm{R}^{2}=0.99 ; \mathrm{n}=10$.

$<1 \%$ bolus particles were $>18 \mathrm{~mm}$.

$\Delta$ 19- through 23-mm particles. $<1 \%$ hay particles were $>23 \mathrm{~mm}$.

g)

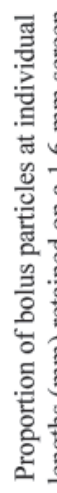

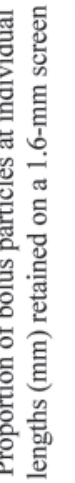

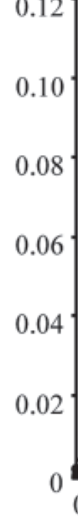

Proportion of corn silage particles at individual lengths $(\mathrm{mm})$ retained on a 1.6- $\mathrm{mm}$ screen

- 1-mm particle.

- 2- through 32-mm particles; $\mathrm{y}=1.098 \mathrm{x}-0.002 ; \mathrm{R}^{2}=0.97 ; \mathrm{n}=31$.

$<1 \%$ bolus particles were $>32 \mathrm{~mm}$.

^ 33- through 45-mm particles.

$<1 \%$ silage particles were $>45 \mathrm{~mm}$.

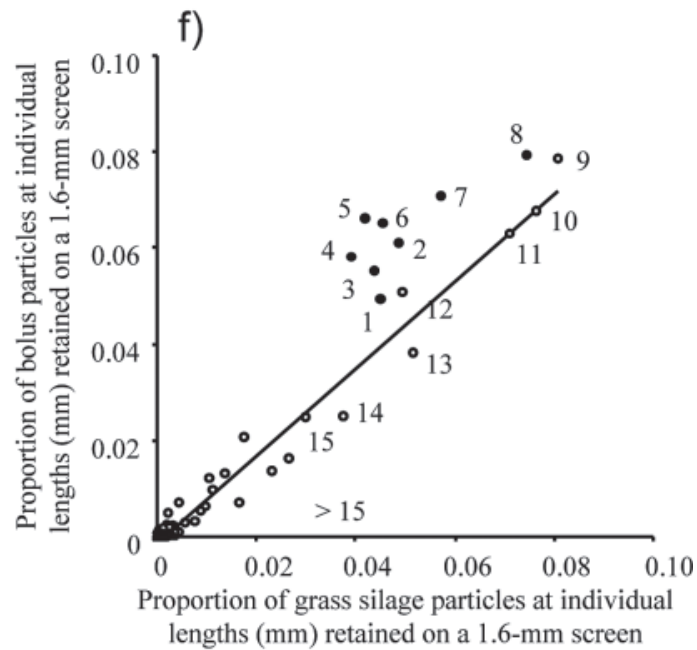

- 1- through 8-mm particles.

- 9- through 38-mm particles; $\mathrm{y}=0.906 \mathrm{x}-0.001 ; \mathrm{R}^{2}=0.97 ; \mathrm{n}=30$.

$<1 \%$ bolus particles were $>38 \mathrm{~mm}$.

- 39- through 57-mm particles.

$<1 \%$ silage particles were $>57 \mathrm{~mm}$.

h)

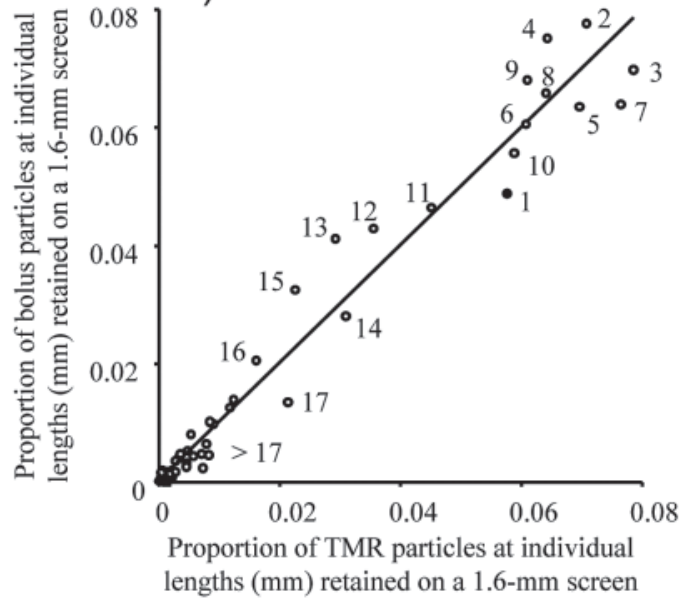

- 1-mm particle.

- 2- through 45-mm particles; $\mathrm{y}=0.995 \mathrm{x} ; \mathrm{R}^{2}=0.97 ; \mathrm{n}=44$.

$<1 \%$ bolus particles were $>45 \mathrm{~mm}$.

- 46- through 49-mm particles.

$<1 \%$ TMR particles were $>49 \mathrm{~mm}$.

Figure 3 (Continued). Length distribution of feed particles relative to respective bolus particles from image analysis (dry and lactating cows averaged, a to h); image analysis after elimination of small particles by sieving through a 1.6-mm screen from all bolus samples (a to h) and chopped rye grass hay retained on the 1.18-mm screen of the Penn State Particle Separator (1.18_PSPS hay), grass silage, corn silage and TMR (e to $\mathrm{h}$ ); direct image analysis from unprocessed long rye grass hay, 50-mm hay, 19_PSPS hay and 8_PSPS hay (a to d). The numbers in the body of each graph are the particle lengths $(\mathrm{mm})$. a) Long rye grass hay; b) 50-mm hay versus respective bolus particles; c) 19_PSPS hay versus respective bolus particles; d) 8_PSPS hay versus respective bolus particles; e) 1.18_PSPS hay versus respective bolus particles; f) grass silage particles versus respective bolus particles; g) corn silage particles versus respective bolus particles; h) TMR particles versus respective bolus particles. 
imaged 9- to 38-mm and fewer 1- to 8-mm particles in the grass silage samples compared with the respective boli. Corn silage and TMR particle proportions were linearly associated $\left(\mathrm{R}^{2}=0.97\right)$ with bolus particle proportions over almost the full range of bolus particle lengths (Figure $3 \mathrm{~g}$ and $3 \mathrm{~h}$ ). These figures suggest that feed boli were swallowed with little particle reduction, as plots essentially have a slope close to 1 , with an intercept close to 0 .

\section{Overestimation of Particles Equal to or Longer Than $5 \mathrm{~mm}$}

We were concerned about whether or not the prescreening through the $1.6-\mathrm{mm}$ sieve would well separate particles of $5-\mathrm{mm}$ lengths or longer from those with lengths less than $5 \mathrm{~mm}$. The abscissa in Figure 4 presents the proportion of particles retained on the 1.6-mm screen for feed and bolus particles (black diamonds) and rumen mat and fecal particles (clear diamonds) against the proportion of particles shorter than $5 \mathrm{~mm}$ but retained on the $1.6-\mathrm{mm}$ screen. Figure 4 shows that PROP_1.6 exceeds the mass proportion of particles equal to or longer than $5 \mathrm{~mm}$. Six up to $65 \%$ of the particles, referred to the total number of particles, retained on the $1.6-\mathrm{mm}$ screen were shorter than $5 \mathrm{~mm}$. We observed systematically higher proportions of particles shorter than $5 \mathrm{~mm}$, the fewer the particles that were retained on that sieve. The error in mass estimation was highest in fecal and rumen mat samples and lowest in the treatment feeds with the longer particles. Estimates of a mean length of particles equal or longer than $5 \mathrm{~mm}$ could be biased if all imaged particles, even those shorter than $5 \mathrm{~mm}$, were used for calculation. This bias would increase with a decrease in the size of the analyzed particles. We could have substituted the 1.6-mm screen by another sieve with openings larger than $1.6 \mathrm{~mm}$ but then we would have compromised our decision to analyze lengths of all particles equal to or longer than $5 \mathrm{~mm}$. Especially in the analysis of treatment feeds with longer particles, there was a risk of overestimating mean length of particles equal to or longer than $5 \mathrm{~mm}$ using a sieve with bigger openings. A precise mass estimation of particles equal to or longer than $5 \mathrm{~mm}$ might require a variation of screens with differing openings, depending on dimension of particles to analyze. Screens with larger openings might be needed to separate particles equal to or longer than 5 $\mathrm{mm}$ in fecal or rumen mat samples compared with feed samples with long particles, but it would be probably rather difficult to define individual sieve sizes to use for individual samples.

We could approximately estimate an error in terms of numerical proportion of particles shorter than $5 \mathrm{~mm}$, retained on the 1.6-mm screen, from the DM proportion of particles retained. The extent of overestimation of the mass of particles equal to or longer than $5 \mathrm{~mm}$ is probably less severe relative to the numerical proportion of particles shorter than $5 \mathrm{~mm}$ measured on the screen. Especially in the case of only forage particles, the shorter particles supposedly also have lower weights compared with the longer ones. If particle size reduction during mastication was measured, some of the error might be reduced by the fact that in both measurements (feed and bolus), overestimation occurred.

\section{Feed and Bolus Particle Size (PROP_1.6 and ML) and Ingestive Mastication (Chews/g of DM)}

Feed and bolus PROP_1.6, ML, and chews per gram of DM are reported in Table 3.

Particle Size of Treatment Feeds. Long hay, the 50-mm hay, the 19_PSPS hay, and 8_PSPS hay were not presieved through the $1.6-\mathrm{mm}$ screen, as all particles were apparently longer than $5 \mathrm{~mm}$. Furthermore, it was likely that $100 \%$ of these particles were retained on the 1.6-mm screen, as $80 \%$ of particles from the finer 1.18_PSPS hay were retained on the 1.6-mm screen. The PSPS_pan hay with the finest particles had PROP_1.6 of only 0.33 . Grass silage particles had a PROP_1.6 of 0.66 , which was similar $(P>0.05)$ to the 1.18_PSPS hay. Corn silage and TMR had intermediate PROP_1.6 of 0.52 and 0.44 , respectively.

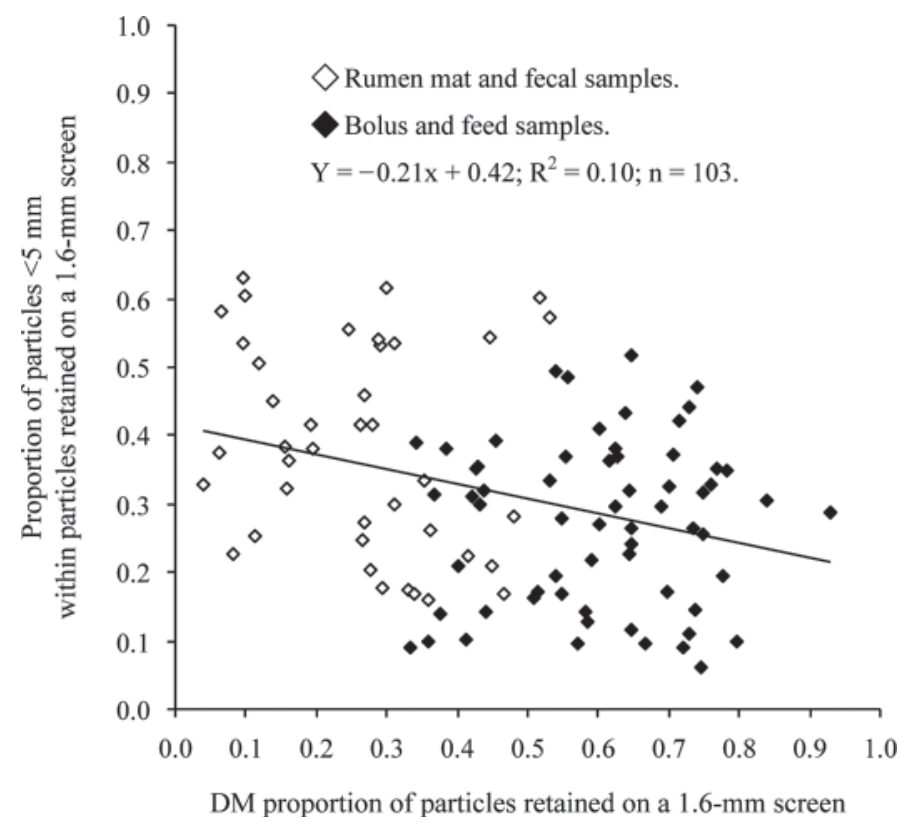

Figure 4. Proportion of particles retained on a 1.6-mm screen that are shorter than $5 \mathrm{~mm}$. The proportion of particles (y-axis) refers to the total number of particles. 
Table 3. Particle size reduction and number of chews during ingestive mastication: LSM and SEM of proportional dry residues on a 1.6-mm screen (PROP_1.6), mean lengths (ML) of particles retained on a 1.6-mm screen and $\geq 5 \mathrm{~mm}$, and chews per gram of DM ingested

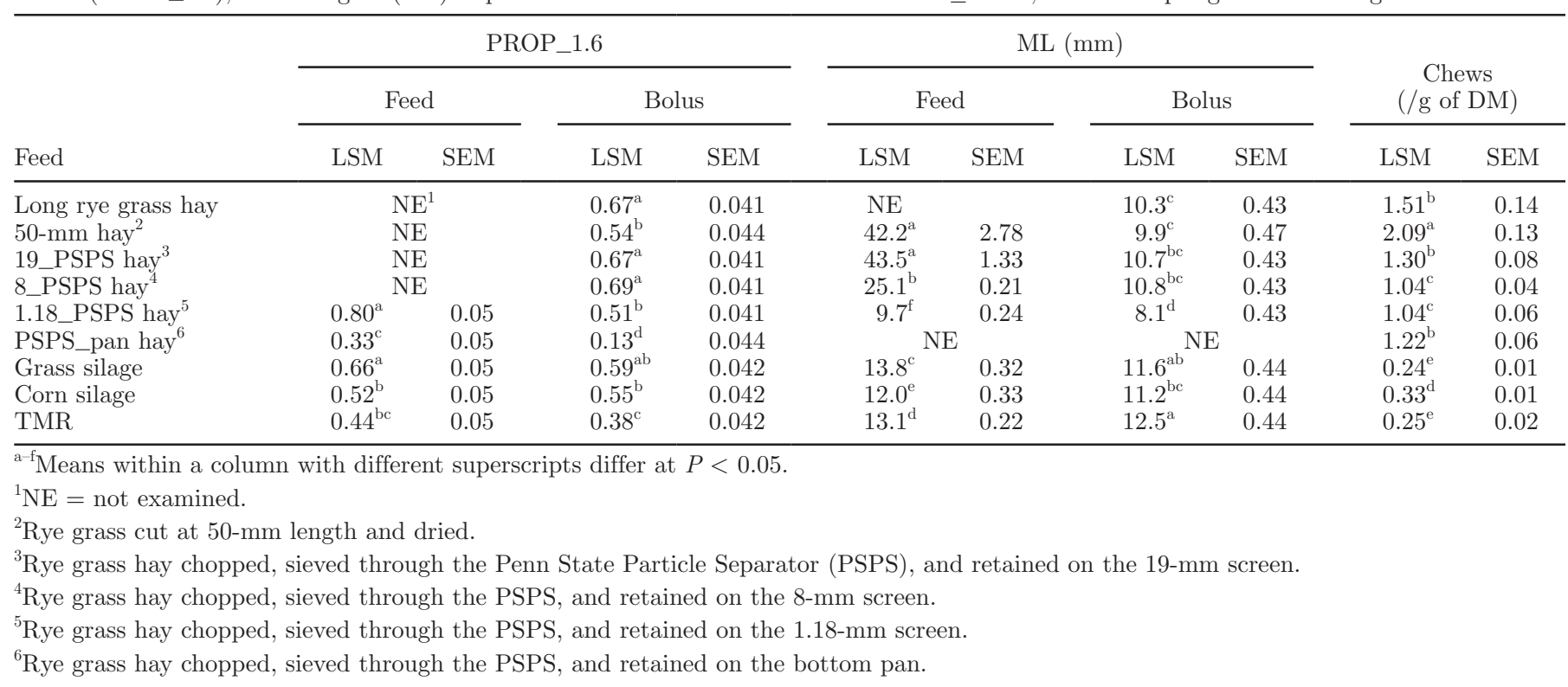

Effects of Feed Particle Size on Bolus Particle Size. The long hay was not analyzed for length by image analysis, but selected material was measured by hand using calipers and all selected long hay particles were longer than $600 \mathrm{~mm}$. The ML of the imaged 50$\mathrm{mm}$ hay particles were similar $(P>0.05)$ to the ML of the 19_PSPS hay (42.2 vs. $43.5 \mathrm{~mm})$. The $8 \_P S P S$ hay and 1.18_PSPS hay had lower ML (25.1 and 9.7 $\mathrm{mm}$, respectively). Imaged grass silage, corn silage, and TMR particles had ML of 13.8, 12.0, and $13.1 \mathrm{~mm}$, respectively.

Rye grass hay particles longer than those retained on the 1.18-mm PSPS screen, with exception of the $50-\mathrm{mm}$ hay, all had similar bolus PROP_1.6 $(P>0.05)$, which ranged between 0.67 and 0.69 , and bolus ML ranging between 10.3 and $10.8 \mathrm{~mm}$. Rye grass hay was apparently chewed to a constant bolus ML, independent of distributions of feed particle lengths, as long as hay particles were long enough to be retained on the 8-mm PSPS screen, with minimum ML of $25.1 \mathrm{~mm}$. The 1.18_PSPS hay had a smaller bolus PROP_1.6 of 0.51 and shorter bolus ML of $8.1 \mathrm{~mm}$. The PSPS_pan hay and respective bolus particles were not imaged. Bolus PROP_1.6 of the PSPS_pan hay was only 0.13. The findings of our experiment are similar to observations made by Shaver et al. (1988). In this study, particle size of masticate particles and particle distribution on sieves were not different for chopped and long alfalfa hay; however, pelleted hay had smaller particle size and more particles collected on small sieves. In the literature, several authors found bolus particle size not affected by feed particle size. Pan et al. (2003) measured particle size distribution of boli of orchard grass stems cut at 100 and $20 \mathrm{~mm}$ and ground to pass through a $10-\mathrm{mm}$ sieve. Particle size distribution of boli captured via an esophageal fistula was very similar among treatments. Bailey et al. (1990) found mean particle length of boli unchanged when long or chopped timothy hay was fed. Schwab et al. (2002) and Fernandez et al. (2004) analyzed masticate particles from whole-plant corn silage of different lengths. In both studies, no effect of forage particle size on bolus mean particle length was observed. Other authors found decreased bolus particle size when feed particle size was decreased. Beauchemin et al. (2003) measured a trend $(P=0.12)$ for decreased mean bolus particle length when diets contained ground versus chopped alfalfa hay. Kononoff and Heinrichs (2003) observed a trend $(P=0.06)$ for shorter digesta mean particle length when diets with shorter alfalfa haylage particles were fed. Results from the current study suggest that the ML of 10 to $11 \mathrm{~mm}$ might represent the maximum ML of rye grass hay particles that the cows were able to swallow. Similar to the present study, Luginbuhl et al. (1989) reported that there might be an appropriate size for bolus formation and subsequent swallowing. In that study, coastal Bermudagrass hay was fed to steers at 4 levels of intake. Boli of the ingested, masticated hay were collected, separated by wet sieving and lengths of particles retained on the 2 larger sieves were determined by image analysis. Reported mean lengths of the masticated and swallowed Bermudagrass hay particles retained on the largest (4-mm) screen were in the range of 10.6 to 12.0 $\mathrm{mm}$. Results of the present study are also in accordance 
with those of Welch and Smith (1978) who fed polypropylene ribbon at different lengths. They recovered $99 \%$ of $10-\mathrm{mm}$-long particles unchewed in the rumen of a partially rumen-evacuated, fistulated steer after feeding.

The threshold ML of rye grass hay particles to affect bolus particle length might be $<25 \mathrm{~mm}$, corresponding to hay particles that pass the 8-mm PSPS screen. Grass hays with ML below this threshold might be more likely to influence parameters such as rumen retention time and intake compared with longer particles. Sieving equipment, to better describe different particle fractions of chopped grass hay that might alter lengths of ingested particles, should probably contain some additional sieves with openings smaller than $8 \mathrm{~mm}$. Openings of these additional screens should probably also be larger than $1.18 \mathrm{~mm}$, because particles passing that screen are considered to not govern retention in the reticulorumen (Kononoff et al., 2003).

Effects of Feed Physical and Chemical Properties on Ingestive Mastication and Bolus Particle Size. The PSPS_pan hay particles were very short and fine and were below the critical particle length required to leave the rumen. However, these particles still stimulated chewing in the present study and mastication reduced PROP_1.6 from 0.33 to 0.13 . The PSPS_pan hay particles were masticated even more intensely relative to the 1.18_PSPS hay particles (1.22 vs. 1.04 chews/g of DM). These treatments were similar $(P>$ $0.05)$ in aNDF contents (53 and 54\% DM; Table 2) and ADL contents (5.5 and 6.0\% DM; Table 2), but the hay with the shortest particles was very powdery and feed might have needed higher insalivation to be swallowed. According to Mertens (1997), chewing activity is a characteristic that reflects the physical as well as the chemical properties of feeds. Physical properties, besides the particle dimensions, might also include features such as dustiness, rigidity, or fragility. The chemical composition of all rye grass hay particles longer than those retained on the 1.18-mm PSPS screen, including also the 50-mm hay, was similar $(P>0.05$; Table 2$)$. However, the uniform cut and drying of fresh material resulted in stiffer, more rigid material compared with material that had been baled and processed through a mixer wagon to create the chopped hay. Baled hay is processed, which may increase the fragility of the stems, which was not the case with the cut hay. According to Casler et al. (1996), fragility is related to the rate of particle size reduction when masticated. All rye grass hay particles longer than those retained on the 1.18-mm PSPS screen, except for the $50-\mathrm{mm}$ hays, had similar bolus particle dimensions. The 50-mm hay had similar bolus ML (9.9 $\mathrm{mm}$ ) but slightly fewer bolus particles retained on the $1.6-\mathrm{mm}$ screen $(54 \%)$ com- pared with long hay (67\%), the 19_PSPS hay (67\%), and the 8_PSPS hay (69\%). Furthermore, the $50-\mathrm{mm}$ hay required a larger number of chews $(2.09$ chews/g of DM) compared with the 19_PSPS hay (1.30 chews/g of $\mathrm{DM})$, despite the fact that both treatments had similar particle ML (42.2 and $43.5 \mathrm{~mm}$, respectively). The number of chews was also higher relative to the chews needed for the long hay (1.51 chews/g of DM), even though the 50-mm hay particles were shorter.

Grass silage, corn silage, and TMR bolus particles had PROP_1.6 of $0.59,0.55$, and 0.38 , respectively, and ML were 11.6, 11.2 , and $12.5 \mathrm{~mm}$, respectively (Table 3). Only approximately $38 \%$ of chewed TMR DM contained particles that were retained on the 1.6mm screen, compared with 54 to $69 \%$ of DM of the rye grass hay treatments with particles longer than those retained on the 1.18-mm PSPS screen. However, the swallowed particles from TMR retained on the 1.6 sieve were longer $(12.5 \mathrm{~mm})$ than those from the hays $(9.9$ to $10.3 \mathrm{~mm}$ ). The TMR had a moisture content of $49 \%$, was lower in aNDF (38\% DM) compared with the hays $(57-59 \% \mathrm{DM})$, and also was lower in ADL (3.7\% DM) compared with the hays (5.5-6.7\% DM). Possibly, the high moisture content aided in swallowing with less need for salivary wetting and chewing and, in addition, low aNDF and ADL content increased particle flexibility and may also have reduced mastication. Rinne et al. (2002) measured shorter rumen particles when maturity and NDF content of ensiled grass increased. De Boever et al. (1993) measured eating time ( $\mathrm{min} / \mathrm{kg}$ of DMI) of grass silages of varying maturity fed to 8 multiparous Holstein cows. Eating time per unit DMI was significantly lower $(P<0.05)$ for grass silage harvested at the vegetative stage with low NDF $(43.6 \% \mathrm{DM})$ compared with grass silage harvested at full maturity with a high NDF content (50.9\% DM). Beauchemin et al. (2003) evaluated the chewing activity in cows fed diets that varied in the ratio of alfalfa silage to alfalfa hay. The alfalfa silage diet had longer particles than the hay diet, but eating time ( $\mathrm{min} / \mathrm{kg}$ of DMI) was lower, possibly due to greater moisture content $(31.7 \%)$ compared with the alfalfa hay diet $(22.4 \%)$. In the current study, the 1.18_PSPS hay and grass silage had similar $(P>0.05)$ PROP_1.6 (0.80 and 0.66, respectively). Contents of aNDF (54 and 53\% DM, respectively) and ADL (6.0 and $6.1 \% \mathrm{DM}$ ) of these treatments were similar, but the grass silage contained $71 \%$ water, whereas the hay was dry. The hay had a shorter particle ML $(9.7 \mathrm{~mm})$ compared with the grass silage $(13.8 \mathrm{~mm})$ but was chewed more intensely (1.04 chews/g of DMI) compared with the silage (0.24 chews/g of DMI).

In our study, TMR and corn silage were not reduced in particle size during ingestive mastication, even though some chewing activity was observed $(0.25$ and 
0.33 chews/g of DMI, respectively). We might have observed some jaw movements in our study that were actually not chewing. The observed chewing activity in this study may not represent well the average chewing behavior during the entire day, as it was detected only over a very short time period of 5 to $15 \mathrm{~min}$, which was the necessary time to collect the bolus samples.

\section{CONCLUSIONS}

Bolus particle size is not necessarily associated to feed particle size. Rye grass hay treatments with ML varying from $25 \mathrm{up}$ to approximately $600 \mathrm{~mm}$ had all the same bolus ML of 10 to $11 \mathrm{~mm}$, independently of feed ML. Rye grass hay particle ML of 10 to $11 \mathrm{~mm}$ might represent the maximum ML the cows were able to swallow. Only for rye grass hay particles with ML shorter than $25 \mathrm{~mm}$, corresponding to the 1.18_PSPS hay, the grass and the corn silage, and the TMR, were the length distributions of feed particles highly correlated to respective bolus particles within a certain range of particle lengths. Rye grass hay particles with ML below this threshold length of $25 \mathrm{~mm}$ might be more likely to influence parameters such as particulate rumen retention time and intake, relative to rye grass hay particles above this critical size. Sieving equipment, to better describe different grass hay particle sizes that might be more related to passage and intake, should probably contain some additional sieve with openings smaller than $8 \mathrm{~mm}$. Feed particles passing a 1.18- $\mathrm{mm}$ screen may not govern retention in the reticulorumen. Grass hay particles that small may barely stimulate rumination. However, in the present study, PSPS_pan hay stimulated ingestive chewing and was reduced in size. Chemical parameters might alter chewing intensity during ingestive mastication. Higher water content and a lower aNDF and ADL content of TMR particles compared with rye grass hay particles might allow bending of particles and the swallowing of longer particles in consequence. Bolus particle size is not associated to the size of large feed particles. Large feed particles are chewed to a threshold size that is acceptable for bolus formation and deglutition. The data of the current study suggest that this size is related to feed chemical composition.

\section{REFERENCES}

Allen, M. S. 1996. Physical constraints on voluntary intake of forage by ruminants. J. Anim. Sci. 74:3063-3075.

Allen, M. S. 2000. Effects of diet on short-term regulation of feed intake by lactating dairy cattle. J. Dairy Sci. 83:1598-1624.

Asadi Alamouti, A., M. Alikhani, G. R. Ghorbani, and Q. Zebeli. 2009. Effects of inclusion of neutral detergent soluble fibre sources in diets varying in forage particle size on feed intake, digestive processes, and performance of mid-lactation Holstein cows. Anim. Feed Sci. Technol. 154:9-23.

Bailey, A. T., R. A. Erdman, L. W. Smith, and B. K. Sharma. 1990. Particle size reduction during initial mastication of forages by dairy cattle. J. Anim. Sci. 68:2084-2094.

Beauchemin, K. A., W. Z. Yang, and L. M. Rode. 2003. Effects of particle size of alfalfa-based dairy cow diets on chewing activity, ruminal fermentation, and milk production. J. Dairy Sci. 86:630-643.

Bhandari, S. K., S. Li, K. H. Ominski, K. M. Wittenberg, and J. C. Plaizier. 2008. Effects of the chop lengths of alfalfa silage and oat silage on feed intake, milk production, feeding behavior, and rumen fermentation of dairy cows. J. Dairy Sci. 91:1942-1958.

Bhandari, S. K., K. H. Ominski, K. M. Wittenberg, and J. C. Plaizier. 2007. Effects of chop length of alfalfa and corn silage on milk production and rumen fermentation of dairy cows. J. Dairy Sci. 90:2355-2366.

Cardoza, R. S. 1985. Threshold size and factors affecting fecal particle weight distribution. MS Thesis. Univ. Georgia, Athens.

Casler, M. D., D. K. Schneider, and D. K. Combs. 1996. Development and application of a selection criterion for particle size breakdown of smooth bromegrass leaves. Anim. Feed Sci. Technol. 61:57-71.

Coulon, J. B., M. Doreau, B. Rémond, and M. Journet. 1987. Evolution des activités alimentaires des vaches laitières en debut de lactation et liaison avec les quantités d'aliments ingérées. Reprod. Nutr. Dev. 27:67-75.

Dado, R. G., and M. S. Allen. 1995. Intake limitations, feeding behavior, and rumen function of cows challenged with rumen fill from dietary fiber or inert bulk. J. Dairy Sci. 78:118-133.

De Boever, J. L., A. M. De Smet, D. L. De Brabander, and C. V. Boucque. 1993. Evaluation of physical structure. 1. Grass silage. J. Dairy Sci. 76:140-153.

Fernandez, I., C. Martin, M. Champion, and B. Michalet-Doreau. 2004. Effect of corn hybrid and chop length of whole-plant corn silage on digestion and intake by dairy cows. J. Dairy Sci. 87:1298-1309.

Goering, H. K., and P. J. Van Soest. 1970. Forage Fiber Analyses (Apparatus, Reagents, Procedures, and Some Applications). Agric. Handbook No. 379. United States Department of AgricultureAgricultural Research Service (USDA-ARS), Washington, DC.

Heinrichs, J., and P. J. Kononoff. 2004. Evaluating particle size of forages and TMRs using the new Penn State Forage Particle Separator. DAS 02-42. Department of Dairy and Animal Science, Penn State University, University Park. Accessed Jun. 7, 2012. http:// www.vetmed.wsu.edu/courses-jmgay/documents/DAS02421.pdf.

Igathinathane, C., L. O. Pordesimo, and W. D. Batchelor. 2008. Ground biomass sieve analysis simulation by image processing and experimental verification of particle size distribution. ASABE Paper No. 084126. American Society of Agricultural and Biological Engineers (ASABE), St. Joseph, MI.

Igathinathane, C., L. O. Pordesimo, E. P. Columbus, W. D. Batchelor, and S. Sokhansanj. 2009. Sieveless particle size distribution analysis of particulate materials through computer vision. Comput. Electron. Agric. 66:147-158.

Kaske, M., and W. von Engelhardt. 1990. The effect of size and density on mean retention time of particles in the gastrointestinal tract of sheep. Br. J. Nutr. 63:457-465.

Kennedy, P. M. 1985. Effect of rumination on reduction of particle size of rumen digesta by cattle. Aust. J. Agric. Res. 36:819-828.

Kononoff, P. J., and A. J. Heinrichs. 2003. The effect of reducing alfalfa haylage particle size on cows in early lactation. J. Dairy Sci. 86:1445-1457.

Kononoff, P. J., A. J. Heinrichs, and D. R. Buckmaster. 2003. Modification of the Penn State forage and total mixed ration particle separator and the effects of moisture content on its measurements. J. Dairy Sci. 86:1858-1863.

Krause, K. M., and D. K. Combs. 2003. Effects of forage particle size, forage source, and grain fermentability on performance and ruminal pH in midlactation cows. J. Dairy Sci. 86:1382-1397.

Lammers, B. P., D. R. Buckmaster, and A. J. Heinrichs. 1996. A simple method for the analysis of particle sizes of forage and total mixed rations. J. Dairy Sci. 79:922-928. 
Lechner-Doll, M., M. Kaske, and W. von Engelhardt. 1991. Factors affecting the mean retention time of particles in the forestomach of ruminants and camelids. Pages 455-482 in Physiological Aspects of Digestion and Metabolism in Ruminants. T. Tsuda, Y. Sasaki, R. Kawashima, ed. Academic Press, San Diego, CA.

Licitra, G., M. Caccamo, I. Schadt, J. D. Ferguson, G. Gennuso, and G. Azzaro. 2005. Method to measure feed particles by image analysis. J. Dairy Sci. 88(Suppl. 1):252. (Abstr.)

Luginbuhl, J.-M., K. R. Pond, J. C. Burns, and J. C. Russ. 1989. Effects of ingestive mastication on particle dimensions and weight distribution of coastal bermudagrass hay fed to steers at four levels. J. Anim. Sci. 67:538-546.

Mertens, D. R. 1997. Creating a system for meeting the fiber requirements of dairy cows. J. Dairy Sci. 80:1463-1481.

Mertens, D. R. 2002. Gravimetric determination of amylase-treated neutral detergent fiber in feeds using refluxing in beakers or crucibles: Collaborative study. J. AOAC Int. 85:1217-1240.

Mertens, D. R. 2005. Particle size, fragmentation index, and effective fiber: Tools for evaluating the physical attributes of corn silages. Pages 211-220 in Proc. Four-State Dairy Nutr. Mgmt. Conf. MWPS-4SD18, Dubuque, IA. Midwest Plan Service, Iowa State Univ., Ames.

Nørgaard, P., and A. Sehic. 2003. Particle size distribution in silage, boluses, rumen content and feces from cows fed grass silage with different theoretical chopping length. Pages 457-460 in Trop. Subtrop. Agroecosyst. 3. Proc. Sixth Int. Symp. Nutr. Herbivores, Merida, Yucatán, Mexico. Universidad Autónoma de Yucatán, Yucatán, Mexico.

Pan, J., S. Koike, T. Suzuki, K. Ueda, Y. Kobayashi, K. Tanaka, and M. Okubo. 2003. Effect of mastication on degradation of orchardgrass hay stem by rumen microbes: Fibrolytic enzyme activities and microbial attachment. Anim. Feed Sci. Technol. 106:69-79.

Poppi, D. P., B. W. Norton, D. J. Minson, and R. E. Hendricksen. 1980. The validity of the critical size theory for particles leaving the rumen. J. Agric. Sci. 94:275-280.

Prigge, E. C., B. A. Stuthers, and N. A. Jacquemet. 1990. Influence of forage diets on ruminal particle size, passage of digesta, feed intake and digestibility by steers. J. Anim. Sci. 68:4352-4360.
Rinne, M., P. Huhtanen, and S. Jaakkola. 2002. Digestive processes of dairy cows fed silages harvested at four stages of grass maturity. J. Anim. Sci. 80:1986-1998.

Schwab, E. C., R. D. Shaver, K. J. Shinners, J. G. Lauer, and J. G. Coors. 2002. Processing and chop length effects in brown-midrib corn silage on intake, digestion, and milk production by dairy cows. J. Dairy Sci. 85:613-623.

Shaver, R. D. 1997. Nutritional risk factors in the etiology of left displaced abomasum in dairy cows: A review. J. Dairy Sci. 80:24492453

Shaver, R. D., A. J. Nytes, L. D. Satter, and N. A. Jorgensen. 1988 Influence of feed intake, forage physical form, and forage fiber content on particle size of masticated forage, ruminal digesta, and feces of dairy cows. J. Dairy Sci. 71:1566-1572.

Stone, W.C. 2004. Nutritional approaches to minimize subacute ruminal acidosis and laminitis in dairy cattle. J. Dairy Sci. 87:(E Suppl.):E13-E26.

Teimouri Yansari, A., and R. Primohammadi. 2009. Effect of particle size of alfalfa hay and reconstitution with water on intake, digestion and milk production in Holstein dairy cows. Animal $3: 218-227$.

Welch, J. G., and A. M. Smith. 1971a. Effect of beet pulp and citrus pulp on rumination activity. J. Anim. Sci. 33:472-475.

Welch, J. G., and A. M. Smith. 1971b. Physical stimulation of rumination activity. J. Anim. Sci. 33:1118-1123.

Welch, J. G., and A. M. Smith. 1978. Particle sizes passed from rumen. J. Anim. Sci. 46:309-312.

Woodford, S. T., and M. R. Murphy. 1988. Effect of forage physical form on chewing activity, dry matter intake, and rumen function of dairy cows in early lactation. J. Dairy Sci. 71:674-686.

Yang, W. Z., and K. A. Beauchemin. 2005. Effects of physically effective fiber on digestion and milk production by dairy cows fed diets based on corn silage. J. Dairy Sci. 88:1090-1098.

Yang, W. Z., K. A. Beauchemin, and L. M. Rode. 2001. Effects of grain processing, forage to concentrate ratio, and forage particle size on rumen $\mathrm{pH}$ and digestion by dairy cows. J. Dairy Sci. 84:2203-2216. 